\title{
ANALISIS KETAHANAN PANGAN PROVINSI SUMATERA BARAT DENGAN METODE REGRESI DATA PANEL
}

\author{
REFNALDO, MAIYASTRI, YUDIANTRI ASDI \\ Program Studi S1 Matematika, \\ Fakultas Matematika dan Ilmu Pengetahuan Alam, Universitas Andalas, \\ Kampus UNAND Limau Manis Padang, Indonesia. \\ email : Refnaldo7@gmail.com
}

\begin{abstract}
Abstrak. Ketahanan pangan merupakan faktor utama dalam menunjang kehidupan manusia. Kondisi ketahanan pangan saat sekarang ini selalu mengalami ancaman krisis pangan, hal ini bisa dilihat dengan selalu bertambahnya jumlah penduduk dan berkurangnya produksi beras dalam negeri. Sumatera Barat yang terdiri dari 19 kabupaten/kota saat ini memiliki kondisi dan karakteristik yang berbeda misalnya kondisi jumlah konsumsi beras, luas areal panen padi, produktivitas lahan dan jumlah penduduk. Oleh karena itu penelitian ini bertujuan untuk menganalisis ketahanan pangan Provinsi Sumatra Barat yang diukur menggunakan kondisi-kondisi tersebut dengan rasio ketersediaan beras sebagai proxy ketahanan pangan. Metode analisis yang digunakan adalah metode regresi data panel. Regresi data panel adalah regresi yang diperoleh dari gabungan data cross section dan time series sehingga diperoleh data yang lebih besar dan dapat meningkatkan presisi dari model regresi yang diperoleh. Hasil penelitian menunjukkan bahwa variabel jumlah penduduk berpengaruh negatif dan signifikan terhadap rasio ketersedian beras dan variabel luas aeal panen padi serta produktivitas lahan berpengaruh positif dan signifikan terhadap rasio ketersediaan beras.
\end{abstract}

Kata Kunci: Ketahanan pangan, regresi, data panel, cross section, time series

$\begin{array}{lll}\text { Diterima } & \text { 29 November } 2018 \\ \text { Direvisi } & : & 3 \text { Desember } 2018 \\ \text { Dipublikasikan } & : & 30 \text { Desember } 2018\end{array}$

\section{Pendahuluan}

Analisis regresi merupakan alat statistika yang memanfaatkan hubungan antara dua variabel atau lebih, pada metode ini salah satu variabel dapat diprediksi dari variabel lainnya. Variabel ini terdiri dari variabel bebas (independent variable) yang biasanya dilambangkan dengan $\mathrm{X}$ dan variabel tergantung (dependent variable) yang biasanya dilambangkan dengan $\mathrm{Y}$. Terdapat beberapa pengembangan analisis regresi, salah satunya regresi data panel. Regresi data panel digunakan untuk mengetahui hubungan antara satu variabel dengan variabel lainnya yang menggunakan data panel. Data panel yaitu data yang merupakan kombinasi data cross section dan time series. Data panel memiliki beberapa kelebihan diantaranya adalah Data panel dapat mendeteksi dan mengukur efek yang tidak bisa diamati dalam data time series atau cross section, dapat meminimumkan bias, bisa memberi data yang lebih informatif, lebih efisien dan dengan data panel kita bisa melihat variabel bebas 
yang berpengaruh maupun yang tidak berpengaruh terhadap variabel tak bebas, sehingga kita bisa dengan mudah untuk menghilangkan variabel yang tidak berpengaruh terhadap model. Ketahanan pangan adalah kondisi terpenuhinya pangan bagi negara sampai dengan perseorangan yang tercermin dari tersedianya pangan yang cukup, baik jumlah maupun mutunya. Ketahanan pangan dapat dipengaruhi oleh banyak faktor, seperti jumlah penduduk, produksi beras, produktivitas lahan, luas areal panen dan bencana alam. Sumatera Barat sebagai salah satu daerah penghasil padi yang mempunyai tingkat produksi padi yang berfluktuasi dari waktu ke waktu. Produksi pada dasarnya merupakan hasil kali luas panen dengan produktivitas lahan. Kondisi luas panen di Sumatera Barat dari waktu ke waktu semakin terancam dengan semakin bertambahnya jumlah penduduk setiap tahun yang menyebabkan permintaan terhadap lahan perumahan dan infrastruktur semakin meningkat. Hal ini juga berdampak tehadap peningkatan jumlah konsumsi beras. Berdasarkan data BPS Sumatera Barat, tingkat Konsumsi beras masyarakat tahun 2016 mencapai 118 kg/kapita/tahun. Kabupaten/kota di Sumatera Barat memiliki kondisi dan karakteristik pangan beras yang berbeda, misalnya jumlah penduduk, luas areal panen dan produktivitas lahan. Kondisi inilah yang akan digunakan untuk menganalisis ketahanan pangan di Sumatera Barat dengan rasio ketersediaan beras sebagai proxy. Metode analisis yang digunakan adalah metode regresi data panel.

\section{Landasan Teori}

Regresi data panel merupakan metode regresi untuk mengetahui hubungan antara variabel bebas terhadap variabel tak bebas dengan menggunakan struktur data panel yaitu gabungan antara data cross section dan data time series. Data cross section merupakan data yang dikumpulkan dalam satu waktu dari sampel, sedangkan data time series merupakan sekumpulan observasi dalam rentang waktu tertentu yang mana data ini dikumpulkan dalam interval waktu secara kontinu.

Ada tiga teknik untuk mengestimasi data panel yaitu : [1]

(1) Common Effect Model (CEM)

Metode common effect diasumsikan bahwa tidak ada perbedaan nilai intersep dan slope pada hasil regresi baik atas dasar karena perbedaan antar individu maupun karena perbedaan waktu. CEM merupakan pendekatan untuk mengestimasi data panel yang paling sederhana. Pada pendekatan ini, seluruh data digabungkan tanpa memperhatikan individu dan waktu. Pada model CEM perilaku data antar individu (cross section) sama dalam berbagai kurun waktu (time series), dengan menggunakan pendekatan Ordinary Least Square (OLS) untuk menduga parameternya. Persamaan metode ini dapat ditulis sebagai berikut.

$$
Y_{i t}=\alpha+\beta_{j} X_{i t}^{j}+\varepsilon_{i t},
$$

dengan:

$Y_{i t}$ : Variabel terikat untuk individu ke- $i$ pada waktu ke- $t$

$X_{i t}^{j}$ : Variabel bebas ke- $j$ untuk individu ke- $i$ pada waktu ke- $t$ 
$i \quad:$ Unit cross section sebanyak $\mathrm{N}$

$t \quad$ : Unit time series sebanyak $\mathrm{T}$

$j \quad$ : Urutan variabel

$\varepsilon_{i t}:$ Komponen error untuk individu ke- $i$ pada waktu ke- $t$

$\alpha$ : intercept

$\beta_{j}:$ Parameter untuk variabel ke- $j$

(2) Fixed Effect Model (FEM)

FEM merupakan metode estimasi regresi data panel dengan asumsi bahwa nilai intersep dari unit individu atau unit waktu berbeda, namun dengan slope koefisien yang tetap. Metode FEM mengestimasi data panel dengan menggunakan variabel dummy untuk menangkap adanya perbedaan intersep, model ini juga mengasumsikan bahwa koefisien regresi tetap antar individu dan antar waktu. Metode estimasi parameter pada pendekatan FEM adalah least square dummy variable (LSDV), dimana LSDV merupakan suatu metode yang dipakai dalam pendugaan parameter regresi linear dengan menggunakan OLS pada model variabel dummy untuk intersep yang berbeda pada setiap individu dan waktu. Persamaan FEM dapat dinyatakan sebagai berikut :

$$
Y_{i t}=\sum_{i=1}^{n} \beta_{j} X_{i t}^{j}+\sum_{i=1}^{n} \alpha_{i} D_{t}+\varepsilon_{i t}
$$

dengan:

$Y_{i t}$ : Variabel terikat untuk individu ke- $i$ pada waktu ke- $t$

$X_{i t}^{j}$ : Variabel bebas ke- $j$ untuk individu ke- $i$ pada waktu ke- $t$

$D_{t}:$ Dummy

$j \quad$ : Urutan variabel

$\alpha$ : intercept

$\varepsilon_{i t}:$ Komponen error untuk individu ke- $i$ pada waktu ke- $t$

$\beta_{j}:$ Parameter untuk variabel ke- $j$

$i \quad$ : Unit cross section sebanyak $\mathrm{N}$

$t \quad$ : Unit time series sebanyak $\mathrm{T}$

(3) Random Effect Model (REM)

REM adalah metode regresi yang mengestimasi data panel dengan menghitung error dari model regresi dengan metode Generalized Least Square (GLS). Berbeda dengan fixed effect model, efek spesifikasi dari masing-masing individu diperlakukan sebagai bagian dari komponen error yang bersifat acak dan tidak berkorelasi dengan variabel penjelas yang teramati.

$$
Y_{i t}=\alpha+\beta_{j} X_{i t}^{j}+\varepsilon_{i t} ; \varepsilon_{i t}=U_{i}+V_{t}+W_{i t},
$$

dengan:

$Y_{i t}$ : Variabel terikat untuk individu ke- $i$ pada waktu ke- $t$

$X_{i t}^{j}$ : Variabel bebas ke- $j$ untuk individu ke- $i$ pada waktu ke- $t$

$\varepsilon_{i t}$ : Komponen error untuk individu ke- $i$ pada waktu ke- $t$

$\beta_{j}:$ Parameter untuk variabel ke- $j$

$U_{i}$ : Komponen error cross section 
$V_{t}$ : Komponen error time series

$W_{i t}$ : Komponen error gabungan

$i$ : Unit cross section sebanyak $\mathrm{N}$

$t \quad$ : Unit time series sebanyak $\mathrm{T}$

$j \quad$ : Urutan variabel

$\alpha$ : intercept

Adapun asumsi yang digunakan untuk komponen error tersebut adalah :

$$
\begin{aligned}
& U_{i} \sim N\left(0, \sigma_{u}^{2}\right. \\
& V_{t} \sim N\left(0, \sigma_{v}^{2}\right) \\
& W_{i t} \sim N\left(0, \sigma_{w}^{2}\right)
\end{aligned}
$$

\subsection{Uji Lagrange Multiplier}

Uji Lagrange Multiplier dilakukan untuk menentukan apakah model random effects lebih baik dibandingkan dengan model common effects. [2]

Hipotesis :

$H_{0}$ : model common effect yang terpilih

$H_{1}$ : model fixed effect yang terpilih

Taraf nyata : $=0,05$

Kriteria uji : tolak $H_{0}$ jika $\mathrm{F}$ hitung lebih besar dari $\mathrm{F}$ tabel atau $p-$ value $<\alpha$.

Statistik Uji: $L M=\frac{n T}{2(T-1)} \frac{\sum_{i=1}^{n}\left(T e_{i t}\right)^{2}}{\sum_{i=1}^{n} \Sigma_{t=1}^{T} e_{i t}^{2}}-1$

Keterangan:

$n=$ jumlah unit individu

$T=$ jumlah periode waktu

$e_{i t}=$ nilai residual pada observasi ke- $i$ dan pada periode waktu ke- $t$.

\subsection{Uji Hausmann}

Uji Hausman digunakan untuk memilih diantara model fixed effect dan model random effect serta untuk mengetahui apakah efek individu tidak berkorelasi dengan variabel prediktor. Alasan dilakukannya uji hausman didasarkan pada model FEM yang mengandung suatu unsur trande off yaitu hilangnya unsur derajat bebas dengan memasukkan variabel dummy dan model random effect yang harus memperhatikan ketiadaan pelanggaran asumsi dari setiap komponen galat. [3]

Hipotesis :

$H_{0}$ : model random effect yang terpilih

$H_{1}$ : model fixed effect yang terpilih

Taraf nyata : $=0,05$

Kriteria uji : tolak $H_{0}$ jika $\mathrm{F}$ hitung lebih besar dari $\mathrm{F}$ tabel atau $p-$ value $<\alpha$.

Statistik Uji: 


\section{3. $U j i$ F}

Uji $\mathrm{F}$ dilakukan untuk mengetahui pengaruh semua variabel bebasnya terhadap variabel terikat.

Sedangkan hipotesis dalam uji $\mathrm{F}$ adalah:

$H_{0}: \beta_{1}=\beta_{2}=\cdots=\beta_{j}=0$ (Tidak terdapat variabel bebas yang berpengaruh linear terhadap variabel bebas)

$H_{1}: \beta_{k} \neq 0$, untuk $k=1,2, \cdots, j$ (minimal terdapat satu variabel bebas yang berpengaruh linear terhadap variabel tak bebas) Formula uji statistik F adalah sebagai berikut: [4]

$$
F=\frac{\frac{R^{2}}{k}}{\frac{1-R^{2}}{n T-k-1}}
$$

dengan:

$R^{2}$ : koefisien determinasi

$n$ : jumlah pengamatan

$k$ : jumlah parameter yang diestemasi

$T$ : jumlah time series

Jika Fhitung lebih besar dari Ftabel atau $p-$ value $<\alpha$, maka $H_{0}$ ditolak.

\subsection{Uji $t$}

Uji statistik $t$ pada dasarnya menunjukkan seberapa jauh pengaruh satu variabel bebas secara individual dalam menerangkan variasi variabel tak bebas. [5]

$H_{0}: \beta_{j}=0$ (Tidak ada pengaruh dari variabel $X_{j}$ terhadap $Y$ )

$H_{1}: \beta_{j} \neq 0$ (Ada pengaruh dari variabel $X_{j}$ terhadap $Y$ )

$j=1,2, \cdots, k$

Kriteria uji yang digunakan adalah jika $p-$ value $<\alpha$, maka tolak $H_{0}$.

Statistik Uji:

$$
t_{\text {hitung }}=\frac{\beta}{S E(\beta)}
$$

Keterangan:

$\beta \quad=$ taksiran koefisien slope duga

$S E(\beta)=$ standart error dari koefisien slope duga

\subsection{Koefisien Determinasi}

Koefisisen Determinasi $\left(R^{2}\right)$ merupakan suatu ukuran yang penting dalam regresi, karena dapat menginformasikan baik atau tidaknya model regresi yang terestimasi dan juga koefisien determinasi bertujuan untuk mengukur seberapa besar variasi variabel tak bebas dapat diterangkan oleh variabel bebas. [4]

Formula $R^{2}$ adalah sebagai berikut.

$$
F=\frac{E S S}{T S S}=1-\frac{R S S}{T S S}
$$


dimana TSS merupakan total jumlah kuadrat; ESS merupakan jumlah kuadrat yang dijelaskan; dan $R S S$ merupakan jumlah kuadrat residual.

\subsection{Uji Asumsi Klasik}

Model regresi yang baik adalah model yang menghasilkan estimasi linier tidak bias (Best Linier Unbiased Estimator). Kondisi ini akan terjadi jika dipenuhi beberapa asumsi, yang disebut dengan asumsi klasik. Agar model dapat dianalisis dan memberikan hasil yang representatif, maka model harus memenuhi pengujian asumsi klasik yakni uji heteroskedatisitas dan uji autokorelasi. Untuk model random effect, uji asumsi klasik tidak relevan untuk dilakukan. Hal ini dikarenakan model random effect menggunakan metode estimasi Generalized Least Square (GLS). [4]

\section{Metodologi Penelitian}

\subsection{Data Penelitian}

Data yang digunakan pada peneltian ini adalah data sekunder yang dikumpulkan dari tahun 2012 2016. Data diambil dari website Badan Pusat Statistik (BPS) dan Dinas Ketahanan Pangan (DKP) Provinsi Sumatera Barat. Subjek yang digunakan yaitu seluruh kabupaten/ kota yang ada di Provinsi Sumatera Barat. Data yang telah diperoleh akan diproses menggunakan software stata. Langkah-langkah analisis yang akan dilakukan adalah mencari persamaan common effect model, fixed effect model dan random effect model. Selanjutnya melakukan pemilihan model terbaik dengan uji lagrange multiplier dan uji Hausmann. Kemudian menganalisis variabel bebas untuk mengetahui pengaruh variabel bebas terhadap variabel tak bebas secara individu maupun secara keseluruhan dengan uji statistik yaitu uji F, uji t, koefisien determinasi dan terakhir melakukan uji asumsi klasik. setelah didapat model regresi yang paling tepat, langkah selanjutnya adalah membuat kesimpulan.

\subsection{Variabel}

Variabel-variabel yang digunakan dalam penelitian ini disesuaikan dengan referensi penelitian yang ada, yaitu terdiri dari variabel tak bebas (Rasio ketersediaan beras) dan variabel bebas yang terdiri 3 peubah, yaitu.

(1) Jumlah penduduk (Variabel $X_{1}$ ),

(2) Luas areal panen padi (Variabel $X_{2}$ ),

(3) Produktivitas lahan (Variabel $X_{3}$ ).

\section{Pembahasan}

\subsection{Common Effect Model (CEM)}

Model $C E M$ merupakan pendekatan untuk mengestimasi panel yang paling sederhana, dimana seluruh data digabungkan tanpa memperhatikan individu dan waktu. Berikut output model CEM:

Berikut pendugaan persamaan regresi model $C E M$ :

$$
Y=1,04381-0,0000719 X_{2}+0,044893 X_{3} .
$$




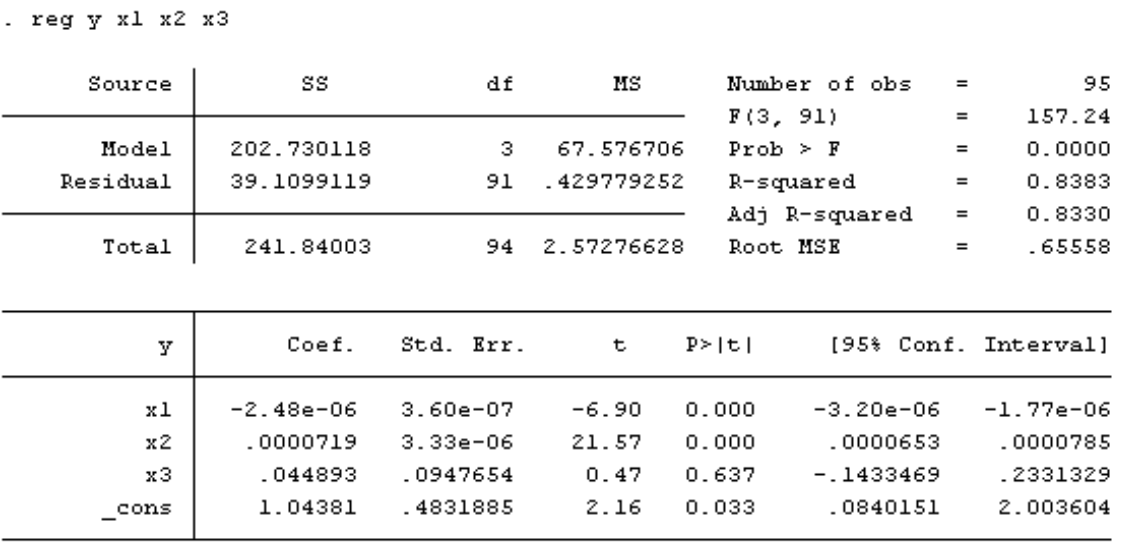

\subsection{Fixed Effect Model (FEM)}

Model FEM merupakan metode estimasi regresi data panel dengan asumsi bahwa nilai intersep dari unit cross section atau time series berbeda, namun dengan slope koefisien yang tetap. Berikut adalah output model FEM.

Berikut ini penduga persamaan regresi untuk model FEM:

$$
\begin{aligned}
Y= & -2,259459-0,00000254 X_{1}+0,0000831 X_{2}+0,4119145 X_{3}+0,0331465 D_{1} \\
& -0,08143 D_{2}-0,0695251 D_{3}-0,3890546 D_{4} .
\end{aligned}
$$

\subsection{Random Effect Model (REM)}

Model REM merupakan model dengan intersep pada pengamatan diasumsikan sebagai variabel random. Berikut adalah output model REM:

Berikut ini penduga persamaan regresi untuk model $R E M$ :

$$
Y=0,204152-0,0000032 X_{1}+0,0000764 X_{2}+0,2260004 X_{3} .
$$

\subsection{Uji Lagrange Multiplier}

\section{Output Uji Lagrange Multiplier}

Berdasarkan hasil output uji lagrange multiplier, maka diperoleh bahwa nilai $p$-value $=0,0000<0,05$, sehingga $H_{0}$ ditolak yang berarti model random effect lebih baik digunakan dibandingkan model common effect.

\subsection{Uji Hausmann}

Output uji Hausmann. Berdasarkan output diperoleh nilai $p$-value sebesar $0,1862>0,05$ yang artinya $H_{0}$ tidak ditolak maka model random effect lebih baik digunakan.

Setelah dilakukan uji Lagrange Multiplier dan Uji Hausmann, maka diperoleh model random effect sebagai model yang paling tepat dalam menjelaskan Analisis Ketahanan Pangan Provinsi Sumatera Barat dengan Metode Regresi Data Panel. 
$\mathrm{R}-\mathrm{sq}$ :

within $=0.7522$

between $=0.6039$

overall $=0.6041$

corr $\left(u_{-} i, X b\right)=-0.6781$ obs per group:

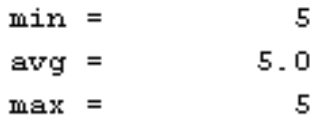

$\mathrm{F}\{7,69)$

Prob > F
29.92 0.0000

\begin{tabular}{|c|c|c|c|c|c|c|}
\hline$y$ & Coef. & Std. Err. & $\mathrm{t}$ & $p>|t|$ & [95 Conf. & Interval] \\
\hline$x 1$ & $2.54 e-06$ & $3.10 e-06$ & 0.82 & 0.414 & $-3.63 e-06$ & $8.72 e-06$ \\
\hline$x 2$ & .0000831 & $8.80 e-06$ & 9.44 & 0.000 & .0000656 & .0001007 \\
\hline$x 3$ & .4119147 & .0648691 & 6.35 & 0.000 & .2825044 & .541325 \\
\hline \multicolumn{7}{|l|}{ tahun } \\
\hline 2013 & .0331469 & .0435053 & 0.76 & 0.449 & -.0536437 & .1199376 \\
\hline 2014 & -.0814303 & .0481017 & -1.69 & 0.095 & -.1773906 & .0145301 \\
\hline 2015 & -.069525 & .053843 & -1.29 & 0.201 & -.1769388 & .0378889 \\
\hline 2016 & -.3890543 & .0593905 & -6.55 & 0.000 & -.5075352 & -.2705734 \\
\hline -cons $^{\text {cons }}$ & -2.259469 & .8563883 & -2.64 & 0.010 & -3.967917 & -.5510208 \\
\hline sigma $u$ & 1.3948196 & & & & & \\
\hline sigma_e & .12890861 & & & & & \\
\hline rho & .99153096 & ifraction & of varia & ce due to & u_i) & \\
\hline
\end{tabular}

\subsection{Uji $F$}

Uji $F$ digunakan untuk melakukan pengujian parameter secara bersamaan. Berikut hipotesis yang digunakan:

$H_{0}: \beta_{1}=\beta_{2}=\cdots=\beta_{j}=0$ (Tidak terdapat variabel yang berpengaruh linear terhadap model)

$H_{1}: \beta_{k} \neq 0$, untuk $k=1,2, \cdots, j$ (Minimal terdapat satu variabel yang berpengaruh linear terhadap model)

Taraf signifikan $(\alpha)$ yang digunakan yaitu 0,05 . Kriteria pengambilan keputusan adalah $H_{0}$ ditolak jika nilai Fhitung $>F(\alpha, k, n-k-1)$ atau $p-$ value $<\alpha$.

Berdasarkan output pada model REM diperoleh nilai $F$ hitung sebesar 276, $20>$ $F(0,05: 4,89)$ sebesar 2,474 dan diperoleh $p-$ value $=0,0000<0,05$ maka $H_{0}$ ditolak berarti secara simultan atau bersamaan terdapat minimal satu variabel bebas $(X)$ yang berpengaruh signifikan terhadap variabel tak bebas $(Y)$. 


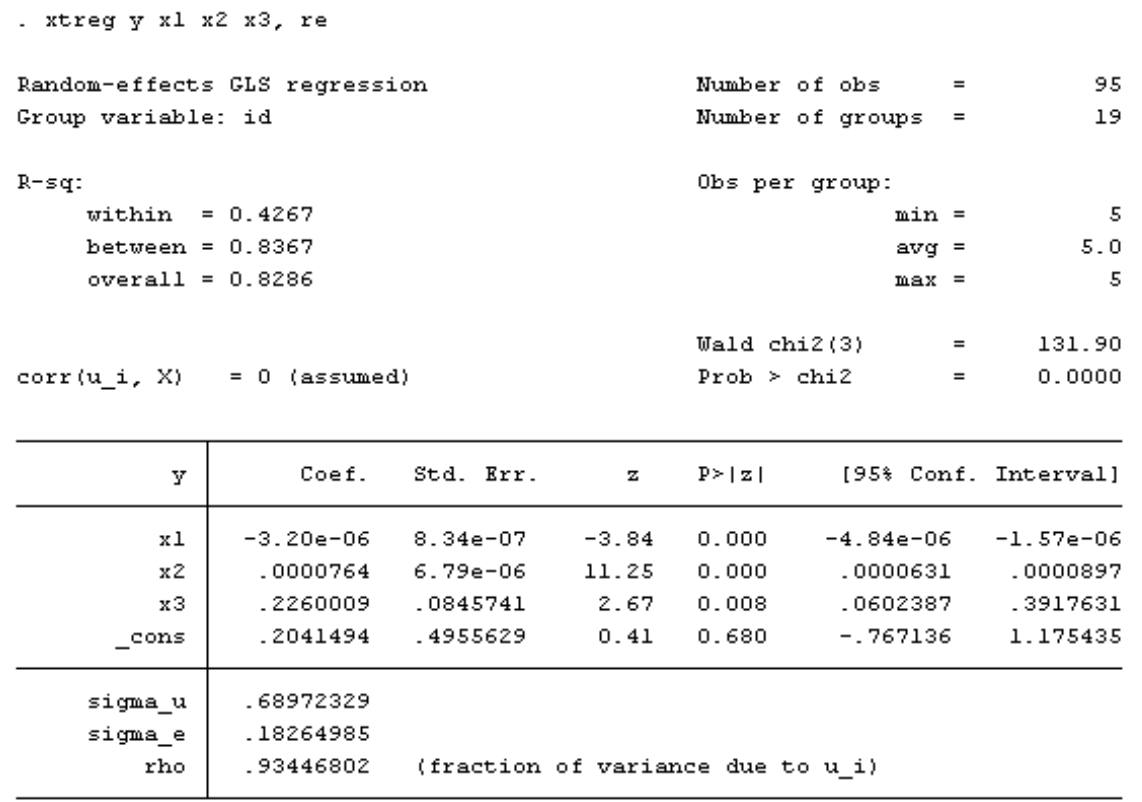

xttest 0

Breusch and Pagan Lagrangian multiplier test for random effects

$y[i d, t]=X b+u[i d]+e[i d, t]$

Estimated results:

\begin{tabular}{c|cc} 
& Var & sd $=$ sqrt (Var) \\
\hline $\mathrm{y}$ & 2.572766 & 1.603985 \\
$\mathrm{e}$ & .033361 & .1826498 \\
$\mathrm{u}$ & .4757182 & .6897233
\end{tabular}

Test: $\operatorname{Var}(u)=0$

chibar2(01) $=156.28$

prob>chibar2 $=0.0000$

\subsection{Uji $t$}

Berdasarkan output model random effect, diperoleh nilai $p$ - value semua variabel bebas $(X)$ sebesar 0,0000 . Karena nilai $p$-value semua variabel bebas $(X)$ kecil $\alpha(0,05)$. Sesuai dengan kriteria pengambilan keputusan, maka $H_{0}$ ditolak. Artinya semua variabel bebas $(X)$ berpengaruh signifikan terhadap variabel tak bebas $(Y)$. 


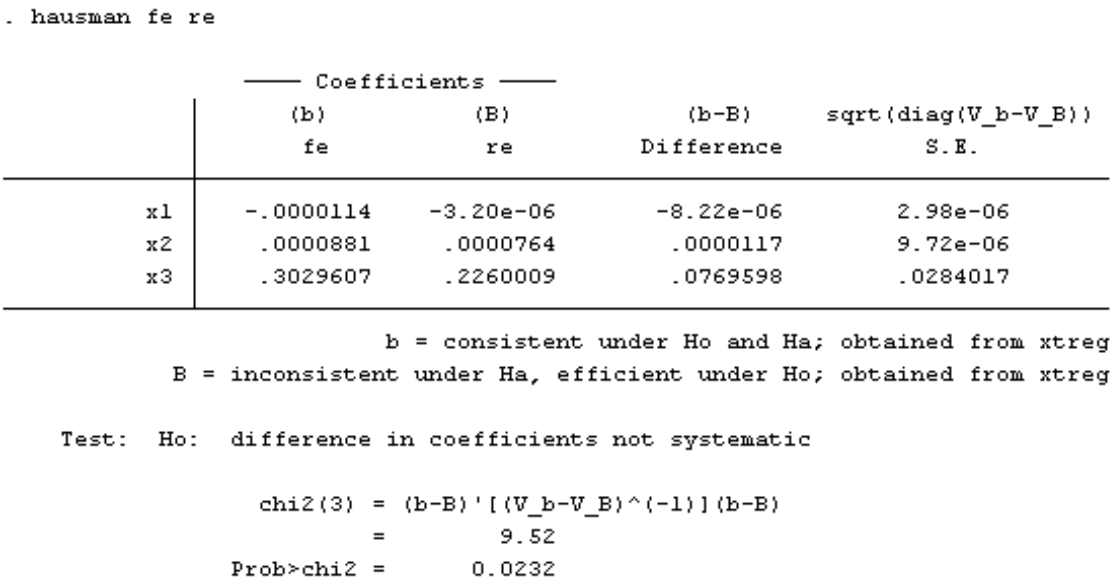

\subsection{Uji Asumsi Klasik}

Dengan terpilihnya model random effect maka tidak relevan untuk dilakukan uji Asumsi Klasik. Hal ini dikarenakan model random effect menggunakan metode estimasi Generalized Least Square (GLS). Teknik GLS dipercaya mengatasi adanya autokorelasi runtun waktu serta korelasi antar observasi dan Metode GLS menghasilkan estimator untuk memenuhi sifat Best Linier Unbiased Estimation (BLUE) yang merupakan metode treatment untuk mengatasi pelanggaran asumsi heteroskedastisitas dan autokorelasi. [5]

\subsection{Koefisien Determinasi}

Nilai koefisien determinasi yang diperoleh berdasarkan output random effect diperoleh sebesar 0,8248. Hal ini berarti sebesar 82,48 persen variasi ketahanan pangan dapat dijelaskan oleh 3 variabel bebas yaitu jumlah penduduk, luas panen dan ratarata produksi beras dan sisanya 18,08 persen dijelaskan oleh variabel lain diluar model.

\section{Kesimpulan}

Berdasarkan analisis yang telah dilakukan maka dapat ditarik kesimpulan:

(1) Seluruh variabel bebas yaitu jumlah penduduk, luas areal panen padi dan rata-rata produksi berpengaruh secara individu maupun secara keseluruhan terhadap rasio ketersediaan beras dengan menggunakan metode random effect model (REM).

(2) Interpretasi dari regresi metode data panel yang sesuai untuk analisis ketahanan pangan Provinsi Sumatera Barat yaitu Variabel luas areal panen dan rata-rata produksi beras berpengaruh positif terhadap rasio ketersediaan beras di provinsi Sumatera Barat. Kenaikan luas areal panen padi sebesar 1 hektar dan ratarata produksi beras sebesar 1 ton akan meningkatkan rasio ketersediaan beras 
berturut-turut sebesar 0,0000764 dan 0,226000. Setiap bertambahnya jumlah penduduk sebanyak 1 jiwa akan menyebabkan penurunan rasio ketersediaan beras sebesar 0,0000032 .

\section{Daftar Pustaka}

[1] Green, W.H. 2003. Econometric Analysis. Person Education. Inc. New Jersey.

[2] Gujarati, D.N. 2004. Basic Econometrics, Mc. Graw Hill Company. New York.

[3] Baltagi BH. 2005. Econometric Analysis of Panel Data, Ed.3. John Wiley and Sons, Ltd. England.

[4] Hasman Hasyim. 2007. Analisis Faktor-Faktor yang Mempengaruhi Ketersediaan Beras di Sumatera Utara. Sekolah Pasca Sarjana Universitas Sumatera Utara. Tesis. 